\title{
Intravenous maintenance fluid therapy in children
}

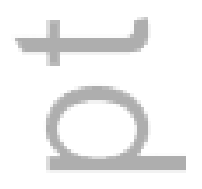

Review article

Author: Dr Sarah McNab

Affiliations: Department of General Medicine, The Royal Children's Hospital, Melbourne, Australia

Murdoch Childrens Research Institute, Melbourne, Australia

Department of Paediatrics, The University of Melbourne, Melbourne, Australia

Date: $17^{\text {th }}$ November, 2015

Word count: 2087 (excluding tables and references)

\section{Correspondence: sarah.mcnab@rch.org.au}

Address: Department of General Medicine, The Royal Children's Hospital, Flemington Rd, Parkville, Australia, 3052

Phone: +61 393454154

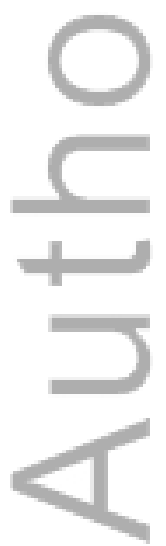

This is the author manuscript accepted for publication and has undergone full peer review but has not been through the copyediting, typesetting, pagination and proofreading process, which may lead to differences between this version and the Version of Record. Please cite this article as doi: 10.1111/jpc.13076

This article is protected by copyright. All rights reserved. 


\section{Abstract}

Intravenous fluids are frequently used in paediatrics, but have been associated with significant adverse outcomes. Understanding the composition of fluid prescribed and administering an appropriate rate is essential for safe fluid administration, along with regular monitoring. Recent evidence has shown that using an isotonic fluid with a sodium concentration similar to plasma can „decrease the risk of hyponatraemia without an increase in adverse effects. This should lead to a change in guidelines: isotonic fluid should now be used as the primary maintenance intravenous fluid given to the majority of children.

Keywords

Intravenous fluid, children, paediatrics, hydration, isotonic, hypotonic (U)
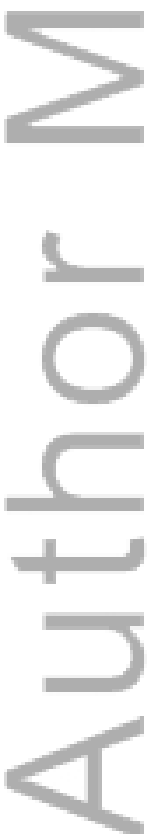

This article is protected by copyright. All rights reserved. 
Intravenous fluids are commonly used in children who have a significantly reduced oral intake. Maintaining hydration by using intravenous fluids has, undoubtedly, saved countless lives. However, serious complications including mortality can result from intravenous fluid use. This harm can arise from the wrong volume, inappropriate composition of IV fluid, and intravenous cannula complications including extravasation, infection or thrombosis. Care should be taken in the prescription, administration and monitoring of intravenous maintenance hydration in children. Understanding the composition of prescribed fluid, and the factors affecting the fluid status of the child are paramount for safe intravenous fluid use.

Where possible, enteral or nasogastric fluid should be administered to children. Where this is not possible, intravenous fluids should be used as required. This report summarises recent evidence for maintenance intravenous fluid therapy in children (outside of the neonatal period) and includes recommendations for practice.

\section{Tonicity of intravenous fluids:}

Intravenous fluids exist in many compositions. In general, fluids can be described as being hypotonic, isotonic or hypertonic. Tonicity refers to the ability of a fluid to exert an osmotic force across a cell membrane and is influenced by solutes which cannot readily cross the cell membrane. A fluid with a similar osmolality to plasma is considered isotonic as the osmotic force across a cell membrane will not change. A hypotonic fluid has a lower osmolality when compared with plasma, while a hypertonic fluid has a higher osmolality.

Complicating this principle is that most maintenance intravenous fluids given to children contain glucose. Glucose, in vitro, increases the osmolality of the fluid. Once administered, however, glucose is rapidly taken up by cells ${ }^{1}$, reducing the tonicity of the fluid. Therefore, a bag of intravenous fluid can be considered hyperosmolar prior to administration but, once administered, 
may be isotonic or even hypotonic as the glucose component does not significantly contribute to the osmotic force across the cell membrane.

Table 1 details some readily available intravenous fluids within Australia. Creating some confusion, tonicity labelling of intravenous fluids within Australia is regulated by the Therapeutic Goods Administration (TGA) according to osmolality. This has resulted in some fluids that are isotonic in vivo being labelled as hypertonic, and some fluids that are markedly hypotonic in vivo =being labelled as isotonic.

1

When addressing tonicity, this paper is referring to in vivo tonicity.

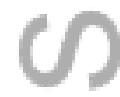

단
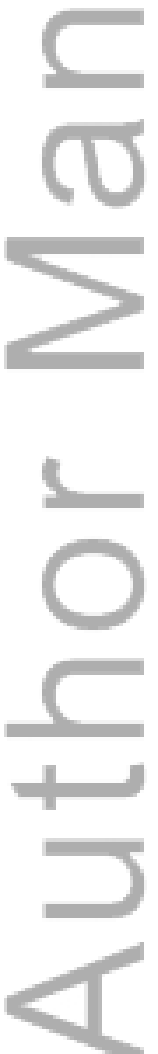

This article is protected by copyright. All rights reserved. 
Table 1 - Commonly available intravenous fluids

\begin{tabular}{|c|c|c|c|c|c|c|c|c|c|}
\hline & $\begin{array}{c}\mathrm{Na}+ \\
(\mathrm{mmol} / \mathrm{L})\end{array}$ & $\begin{array}{c}\mathrm{Cl}- \\
(\mathrm{mmol} / \mathrm{L})\end{array}$ & $\begin{array}{c}\mathrm{K}+ \\
(\mathrm{mmol} / \mathrm{L})\end{array}$ & $\begin{array}{l}\mathrm{Mg}++ \\
(\mathrm{mmol} / \mathrm{L})\end{array}$ & $\begin{array}{l}\text { Calcium } \\
\text { (mmol/L) }\end{array}$ & $\begin{array}{l}\text { Lactate } \\
(\mathrm{mmol} / \mathrm{L})\end{array}$ & $\begin{array}{l}\text { Acetate } \\
\text { (mmol/L) }\end{array}$ & $\begin{array}{l}\text { Gluconate } \\
\text { (mmol/L) }\end{array}$ & $\begin{array}{l}\text { Glucose } \\
\text { (gram/L) }\end{array}$ \\
\hline Plasma & $135-145$ & $98-110$ & $3.5-5$ & $1.0-1.8$ & & & & & $3.6-5.4$ \\
\hline $\begin{array}{l}0.18 \% \text { sodium chloride with } 4 \% \text { glucose } \\
\text { (Hypotonic) }\end{array}$ & 30 & 30 & - & - & - & - & - & - & 40 \\
\hline $\begin{array}{l}0.45 \% \text { sodium chloride with } 2.5 / 5 \% \text { glucose } \\
\text { (Hypotonic) }\end{array}$ & 77 & 77 & - & - & - & - & - & - & $25 / 50$ \\
\hline $\begin{array}{l}\text { Plasmalyte148 solution with } 5 \% \text { glucose } \\
\text { (Isotonic) }\end{array}$ & 140 & 98 & 5 & 1.5 & - & - & 27 & 23 & 50 \\
\hline $\begin{array}{l}0.9 \% \text { sodium chloride with } 5 \% \text { glucose } \\
\text { (Isotonic) }\end{array}$ & 154 & 154 & - & - & - & - & - & - & 50 \\
\hline
\end{tabular}

This article is protected by copyright. All rights reserved. 


\begin{tabular}{|c|c|c|c|c|c|c|c|c|c|}
\hline $\begin{array}{l}\text { Hartmann's solution (similar in ionic } \\
\text { composition to Ringer's lactate) } \\
\text { (Isotonic) }\end{array}$ & 131 & 111 & 5 & - & 2 & 29 & - & - & - \\
\hline
\end{tabular}

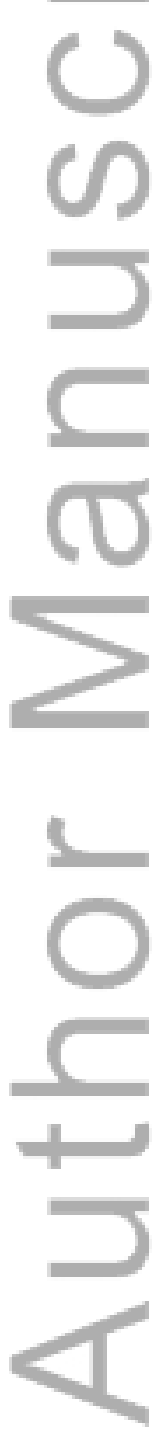




\section{Background to maintenance intravenous fluid prescribing}

In the 1950s, Holliday and Segar published their landmark paper detailing the maintenance fluid volumes required by children ${ }^{2}$. This built on earlier work ${ }^{3-5}$ which related volume requirements to body surface area, and calculated requirements on the basis of weight. Their calculations formed the basis of the $100 / 50 / 20$ or $4 / 2 / 1$ rule that forms the basis of most guidelines used to calculate fluid rates (table 2).

Table 2 - Standard maintenance rates

\begin{tabular}{|l|l|l|}
\hline Weight & Daily fluid requirement & Hourly fluid requirement \\
\hline$<10 \mathrm{~kg}$ & $100 \mathrm{~mL} / \mathrm{kg}$ & $4 \mathrm{~mL} / \mathrm{kg}$ \\
\hline $10-20 \mathrm{~kg}$ & $\begin{array}{l}1000 \mathrm{~mL}+(50 \mathrm{~mL} / \mathrm{kg} \text { for every } \mathrm{kg} \\
\text { of body weight greater than } 10 \mathrm{~kg})\end{array}$ & $\begin{array}{l}40 \mathrm{~mL}+(2 \mathrm{~mL} / \mathrm{kg} \text { for every } \mathrm{kg} \text { of } \\
\text { body weight greater than } 10 \mathrm{~kg})\end{array}$ \\
\hline$>20 \mathrm{~kg}$ & $\begin{array}{l}1500 \mathrm{~mL}+(20 \mathrm{~mL} / \mathrm{kg} \text { for every } \mathrm{kg} \\
\text { of body weight greater than } 20 \mathrm{~kg})\end{array}$ & $\begin{array}{l}60 \mathrm{~mL}+(1 \mathrm{~mL} / \mathrm{kg} \text { for every } \mathrm{kg} \text { of } \\
\text { body weight greater than } 20 \mathrm{~kg})\end{array}$ \\
\hline
\end{tabular}

However, when recommending daily electrolyte requirements, Holliday and Segar stated that "less data are available". They estimated paediatric electrolyte requirements as a midpoint between that received by the consumption of breast milk, and that recommended in adults, concluding that children need approximately $2-4 \mathrm{mmol}$ of sodium per $\mathrm{kg} / \mathrm{day}$. When combining their recommendations of maintenance fluid volumes and these assumed total daily electrolyte requirements, clinicians began prescribing a fluid containing approximately $30 \mathrm{mmol} / \mathrm{L}$ of sodium. Given that plasma contains approximately $140 \mathrm{mmol} / \mathrm{L}$ of sodium, this fluid is markedly hypotonic. This became the basis of intravenous fluid prescribing for the next 50 years.

In the 1990s, case reports started to emerge of deaths as well as severe neurological morbidity secondary to hyponatraemic cerebral oedema in association with hypotonic intravenous fluid administration $^{6-10}$. 
When a hypotonic fluid with a sodium concentration markedly less than plasma is administered intravenously, the osmolality of the intravascular space drops: in essence, it is "diluted"11. The resultant osmotic gradient will drive fluid from the intravascular space into the intracellular space in order to equilibrate the osmolality between the spaces. This influx of water into the intracellular space causes its volume to increase. In the fixed volume of the cranial cavity, there is a limit to the space available for brain tissue expansion. Neurological damage may occur through a combination of direct cell damage, regional hypoperfusion from areas of swelling, loss of autoregulation, and more generalised reduced cerebral perfusion pressure. In extreme cases, an oedematous brain may swell into the base of the skull. Parts of the cerebellum may herniate through the foramen magnum, or part of the cerebral cortex be compressed by the tentorium cerebri, with neurological morbidity or mortality a likely consequence.

Such dire outcomes occur rarely in children who receive hypotonic intravenous fluids. For most, their renal system will compensate for the reduced serum osmolality with an increased excretion of free water. However, sick children are more likely to release anti-diuretic hormone (ADH) as a response to illness. This response reduces the ability of the kidneys to excrete water ${ }^{12}$, markedly reducing the requirement for fluid input. From an evolutionary perspective, this is an important physiological process as the ability to eat or drink is impaired in most serious illnesses. However, when hospitalised patients are administered hypotonic fluids at rates recommended for healthy children, this increases the risk of hyponatraemia and its potential consequences.

Specific patient groups have been thought to be at a higher risk of ADH secretion. These include patients who have undergone craniofacial or spinal surgery and those with head injuries or meningitis ${ }^{13-18}$. However, the conditions known to be associated with increased ADH levels is broad, including common febrile and infectious illnesses, ${ }^{17,19-22}$ and surgical procedures ${ }^{23,24}$. Case reports 
released in 2010 of four paediatric deaths in Canada and the US secondary to hyponatraemic encephalopathy included two previously well children who underwent tonsillectomies and a further patient who had presented with gastroenteritis ${ }^{25}$. These patients would not traditionally be considered to be high risk, but died after receiving hypotonic intravenous fluid.

\section{Composition of intravenous fluid:}

Sodium: In response to concerns regarding hyponatraemia, studies have been conducted over the past decade comparing hypotonic with isotonic intravenous fluid for maintenance hydration in children. A recent Cochrane review ${ }^{26}$, including ten studies of 1106 children - the majority being intensive care patients and/or surgical patients - concluded that isotonic fluid was protective against hyponatraemia when compared with hypotonic fluid (probability of hyponatraemia of $17 \%$ versus $34 \%$; relative risk $0.48 ; 95 \%$ confidence interval $[\mathrm{CI}] 0.38$ to 0.60 ). A subsequent study of an additional 690 children in a broad paediatric population also found that isotonic fluid was protective against hyponatraemia ( $4 \%$ versus $11 \%$; odds ratio $0 \cdot 31,95 \% \mathrm{Cl} 0 \cdot 16-0 \cdot 61 ; \mathrm{p}=0 \cdot 001$ ) without evidence of an increase of adverse consequences including hypernatraemia or overhydration ${ }^{27}$.

The results of this research should lead to a significant change in maintenance fluid recommendations:

Isotonic fluid containing a similar sodium concentration to plasma should be the standard intravenous fluid prescribed for maintenance hydration in children.

\section{intravenous fluid prescribed for maintenance hydration in children.}

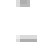

Glucose: The ideal glucose concentration of maintenance fluid has not been well established, with variation in prescribing patterns between paediatric hospitals in Australia, the majority recommending between $2.5 \%$ and $5 \%$ glucose for children (excluding neonates). The work of Neville 
has concluded that $2.5 \%$ glucose may not be adequate to prevent hypoglycaemia, with $15 \%$ of postoperative patients receiving $2.5 \%$ glucose requiring an increase in glucose concentration due to hypoglycaemia and/or ketosis ${ }^{28}$.

Potassium: As with glucose, the ideal potassium concentration for intravenous fluid is poorly understood. Most of the total body potassium is intracellular, so if children are on prolonged intravenous fluids, it is likely they will need an intravenous fluid with a higher concentration of potassium than that in the intravascular space. Recommendations for potassium in maintenance fluid vary, with most guidelines stating that maintenance fluid can contain either no potassium or $20 \mathrm{mmol} / \mathrm{L}$ of potassium. The decision to add potassium may be guided by the serum potassium and the underlying diagnosis.

A paediatric intensive care setting where low $(5 \mathrm{mmol} / \mathrm{L})$ potassium containing fluid was routinely used reported $31 \%$ of patients received additional potassium in their maintenance fluid ${ }^{29}$. This study, published in abstract form only, did not report on the reasons for the addition of potassium or whether hypokalaemia was recorded.

Chloride: $0.9 \%$ sodium chloride contains both sodium and chloride concentrations of $154 \mathrm{mmol} / \mathrm{L}$. This chloride concentration is markedly above that of plasma (which contains approximately $100 \mathrm{mmol} / \mathrm{L}$ ). The extracellular compartment of the body exists in electroneutrality, with the sum of anions equalling the sum of cations. When chloride increases relative to sodium, there is a reciprocal reduction in bicarbonate, ultimately resulting in a metabolic acidosis ${ }^{30-32}$, also known as a hyperchloraemic acidosis. This nomenclature is somewhat of a misnomer, as it is the relative difference between cations and anions which creates the change in $\mathrm{pH}$ (also known as the strong ion 
difference $)^{33}$. That is, the same acidosis can exist with a normal chloride where the sodium level is reduced.

A hyperchloraemic acidosis has been increasingly described as a consequence of $0.9 \%$ sodium chloride infusions ${ }^{34-36}$. In animal and adult studies, hyperchloraemic acidosis has been associated with decreased renal perfusion, decreased gastric perfusion and increased mortality ${ }^{37,38}$.

Balanced solutions, such as Plasmalyte148 or Hartmann's contain less chloride than $0.9 \%$ sodium chloride, resulting in a fluid which is more similar to the electrolyte composition of plasma. These fluids have been shown to carry a lower risk of hyperchloraemic acidosis than $0.9 \%$ sodium chloride 34,35 .

Further research may be required to establish whether a balanced solution, containing a similar chloride concentration to plasma, would result in better paediatric clinical outcomes than $0.9 \%$ sodium chloride when used for maintenance hydration.

Calcium and magnesium: Other components of balanced intravenous fluids include calcium (contained in Hartmann's) and magnesium (contained in Plasmalyte148).

Calcium containing solutions are incompatible with blood products, due to calcium's pro-coagulant effects on citrated blood. In addition, calcium containing products may cause precipitation of ceftriaxone, and are not recommended to be given concurrently ${ }^{39}$.

Magnesium is thought to have less significant incompatibilities, but Plasmalyte148 has had relatively less compatibility testing when compared with $0.9 \%$ sodium chloride or Hartmann's.

\section{Rates for administration}

This article is protected by copyright. All rights reserved. 
As previously described, hospitalised children may have increased levels of anti-diuretic hormone secretion, which reduces their ability to excrete water. The data which established the 100/50/20 or 4/2/1 guidelines for maintenance fluid rate were derived from the estimated water requirements of healthy children. The rates required for hospitalised children are likely to be less. For children who are not dehydrated and those with meningitis or pneumonia, consider commencing intravenous fluids at $1 / 2$ to $2 / 3$ of the standard maintenance rate.

Fluid input, in addition to the maintenance rates prescribed, should be appreciated. Unwell children receiving multiple antibiotics and other drugs are likely to be receiving substantial fluid volumes with drug administration. Children's oral intake should also be considered, with the maintenance fluid volume adjusted accordingly.

\section{Fluid monitoring}

All children receiving intravenous fluids should have regular monitoring of their hydration status, with subsequent adjustment of their fluid prescription. This includes monitoring their weight, assessing their input and output, a clinical assessment and checking of their serum electrolytes.

Monitoring should be initially performed six hours after starting intravenous fluid and at least daily thereafter. More frequent monitoring should occur in patients who are particularly unwell. Case reports have described children becoming clinically unwell and dying from IV fluid associated complications within 24 hours of starting therapy $y^{6,25}$. Fluid input should be considered as a potential contributor whenever there is a clinical deterioration in a child receiving intravenous fluid.

\section{Conclusions}

Recent research in children should lead to a significant change in guidelines for intravenous maintenance fluid therapy: an isotonic fluid with a similar sodium concentration to plasma should 
be used in the majority of children. There are a number of isotonic fluid options to consider, but a balanced fluid with less chloride than sodium may be the most appropriate. In a non-dehydrated child, a starting infusion rate of less than the previously recommended $100 / 50 / 20$ or $4 / 2 / 1$ rate should be considered.

Intravenous fluid should be considered to be a drug prescription and, similarly, the benefits and side effects need to be balanced. Regular monitoring with appropriate changes to the fluid prescription $=$

is paramount to ensure the safety of children receiving maintenance intravenous fluid therapy.

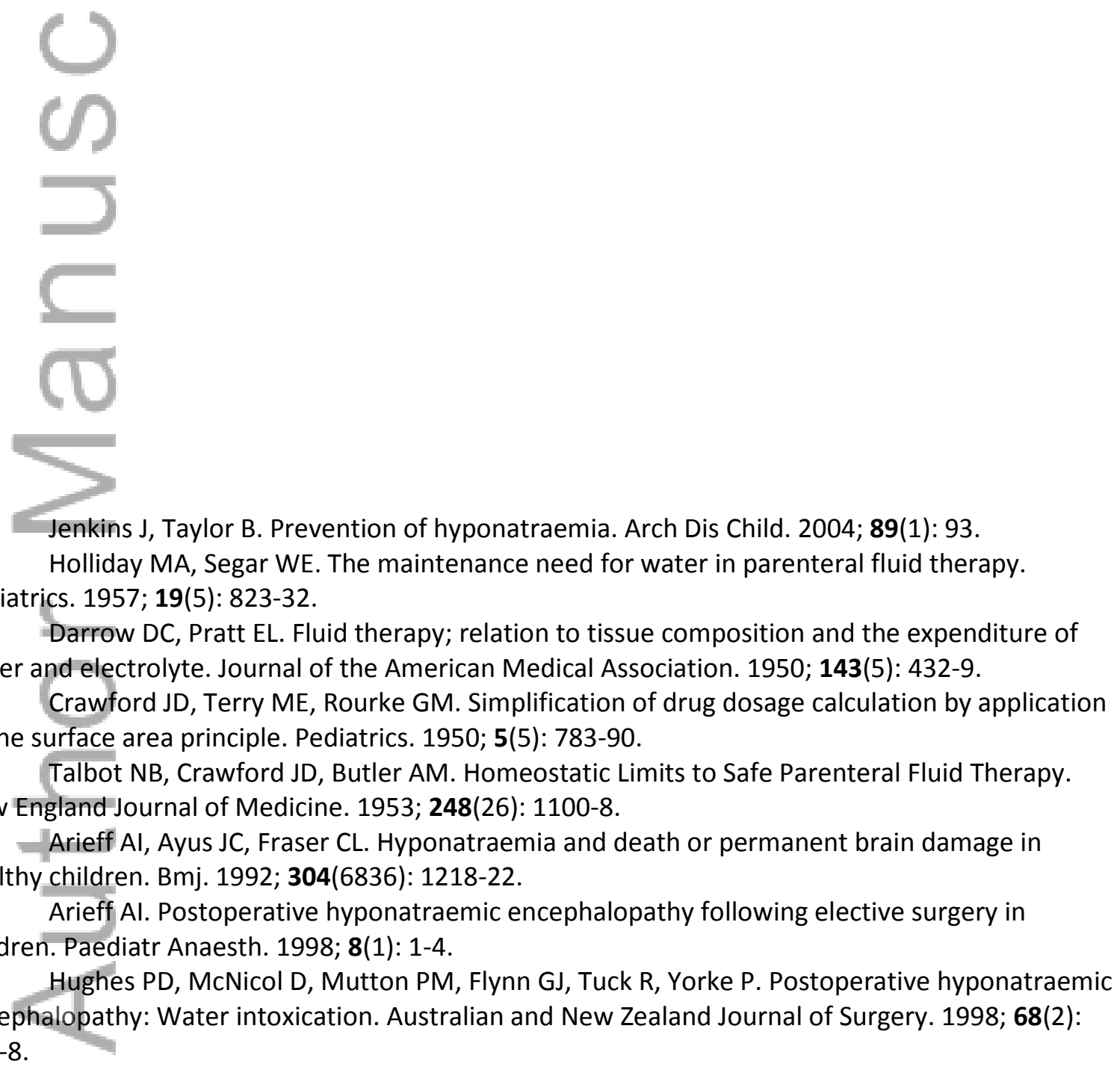
165-8. 
9. Halberthal M, Halperin ML, Bohn D. Acute hyponatraemia in children admitted to hospital: retrospective analysis of factors contributing to its development and resolution. Bmj. 2001;

322(7289): 780-2.

10. Soroker D, Ezri T, Lurie S, Feld S, Savir I. Symptomatic hyponatraemia due to inappropriate antidiuretic hormone secretion following minor surgery. Canadian Journal of Anaesthesia. 1991; 38(2): 225-6.

11. Adrogué HJ, Madias NE. Hyponatremia. New England Journal of Medicine. 2000; 342(21): $1581-9$

12. O'Donoghue D, Trehan A. SIADH and hyponatraemia: foreword. NDT Plus. 2009; 2(suppl 3): iii1-iii4.

13. Chemtob S, Reece ER, Mills EL. SYndrome of inappropriate secretion of antidiuretic hormone in enteroviral meningitis. American Journal of Diseases of Children. 1985; 139(3): 292-4.

14. Elster AD. Hyponatremia after spinal fusion caused by inappropriate secretion of antidiuretic hormone (SIADH). Clinical Orthopaedics \& Related Research. 1985; (194): 136-41.

15. Shann F, Germer S. Hyponatraemia associated with pneumonia or bacterial meningitis. Arch Dis Child. 1985; 60(10): 963-6.

16. Vingerhoets $\mathrm{F}$, de Tribolet N. Hyponatremia hypo-osmolarity in neurosurgical patients.

"Appropriate secretion of ADH" and "cerebral salt wasting syndrome". Acta Neurochir (Wien). 1988; 91(1-2): 50-4.

17. Fajardo JE, Stafford EM, Bass JW, Roscelli JD, Sato AK, Claybaugh JR. Inappropriate antidiuretic hormone in children with viral meningitis. Pediatric Neurology. 1989; 5(1): 37-40.

18. Padilla G, Leake JA, Castro R, Ervin MG, Ross MG, Leake RD. Vasopressin levels and pediatric head trauma. Pediatrics. 1989; 83(5): 700-5.

19. Hasegawa H, Okubo S, Ikezumi Y, Uchiyama K, Hirokawa T, Hirano H, et al. Hyponatremia due to an excess of arginine vasopressin is common in children with febrile disease. Pediatric Nephrology. 2009; 24(3): 507-11.

20. Mori J, Miura M, Shiro H, Fujioka K, Kohri T, Hasegawa T. Syndrome of inappropriate antidiuretic hormone in Kawasaki disease. Pediatrics International. 2011; 53(3): 354-7.

21. Dhawan A, Narang A, Singhi S. Hyponatraemia and the inappropriate ADH syndrome in pneumonia. Annals of Tropical Paediatrics. 1992; 12(4): 455-62.

22. Patwari AK, Singh BS, Manorama DE. Inappropriate secretion of antidiuretic hormone in acute bàcterial meningitis. Annals of Tropical Paediatrics. 1995; 15(2): 179-83.

23. Burrows FA, Shutack JG, Crone RK. Inappropriate secretion of antidiuretic hormone in a postsurgical pediatric population. Critical Care Medicine. 1983; 11(7): 527-31.

24. Judd BA, Haycock GB, Dalton RN, Chantler C. Antidiuretic hormone following surgery in children. Acta Paediatrica Scandinavica. 1990; 79(4): 461-6.

25. Koczmara C, Wade AW, Skippen P, Campigotto MJ, Streitenberger K, Carr R, et al. Hospitalacquired acute hyponatremia and reports of pediatric deaths. Dynamics (Pembroke, Ont). 2010; 21(1): 21-6.

26. McNab S WR, Neville KA, Choong K, Coulthard MG, Duke T, Davidson A, Dorofaeff T. Isotonic versus hypotonic solutions for maintenance intravenous fluid administration in children. Cochrane Database of Systematic Reviews 2014; (12).

27. McNab S, Duke T, South M, Babl FE, Lee KJ, Arnup SJ, et al. $140 \mathrm{mmol} / \mathrm{L}$ of sodium versus 77 $\mathrm{mmol} / \mathrm{L}$ of sodium in maintenance intravenous fluid therapy for children in hospital (PIMS): a randomised controlled double-blind trial. The Lancet. 
28. Neville KA, Sandeman DJ, Rubinstein A, Henry GM, McGlynn M, Walker JL. Prevention of hyponatremia during maintenance intravenous fluid administration: a prospective randomized study of fluid type versus fluid rate. J Pediatr. 2010; 156(2): 313-9.e1-2.

29. Sutherland A, Playfor S. Use of concentrated potassium on PICU increased by the use of a balanced crystalloid. Arch Dis Child. 2013; 98(6): e1.

30. Sirker AA, Rhodes A, Grounds RM, Bennett ED. Acid-base physiology: the 'traditional' and the 'modern' approaches. Anaesthesia. 57(4): 348-56.

31. Stewart PA. Modern quantitative acid-base chemistry. Can J Physiol Pharmacol. 1983; 61(12): 1444-61.

32. Wilkes NJ. Hartmann's solution and Ringer's lactate: targeting the fourth space. Clin Sci. 2003; 104(1): 25-6.

33. Story D. Hyperchloraemic acidosis: another misnomer? . Critical Care and Resuscitation. 2004 Vol. 6( No. 3, Sep): 188-92.

34. McFarlane C, Lee A. A comparison of Plasmalyte 148 and $0.9 \%$ saline for intra-operative fluid replacement. Anaesthesia. 1994; 49(9): 779-81.

35. Reid F, Lobo DN, Williams RN, Rowlands BJ, Allison SP. (Ab)normal saline and physiological Hartmann's solution: a randomized double-blind crossover study. Clin Sci (Colch). 2003; 104(1): 1724.

36. Scheingraber S, Rehm M, Sehmisch C, Finsterer U. Rapid saline infusion produces hyperchloremic acidosis in patients undergoing gynecologic surgery. Anesthesiology. 1999; 90(5): 1265-70.

37. Wilkes NJ, Woolf R, Mutch M, Mallett SV, Peachey T, Stephens R, et al. The effects of balanced versus saline-based hetastarch and crystalloid solutions on acid-base and electrolyte status and gastric mucosal perfusion in elderly surgical patients. Anesth Analg. 2001; 93(4): 811-6.

38. Shaw AD, Bagshaw SM, Goldstein SL, Scherer LA, Duan M, Schermer CR, et al. Major complications, mortality, and resource utilization after open abdominal surgery: $0.9 \%$ saline compared to Plasma-Lyte. Ann Surg. 2012; 255(5): 821-9.

39. Bradley JS, Wassel RT, Lee L, Nambiar S. Intravenous Ceftriaxone and Calcium in the Neonate: Assessing the Risk for Cardiopulmonary Adverse Events. Pediatrics. 2009; 123(4): e609e13.

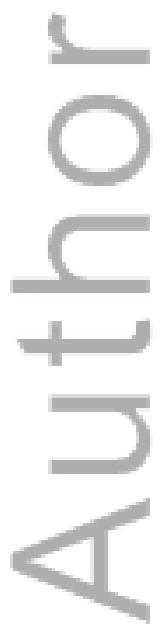

This article is protected by copyright. All rights reserved. 


\section{University Library}

\section{- M M I N E R VA A gateway to Melbourne's research publications}

Minerva Access is the Institutional Repository of The University of Melbourne

Author/s:

McNab, S

Title:

Intravenous maintenance fluid therapy in children

Date:

2016-02-01

Citation:

McNab, S. (2016). Intravenous maintenance fluid therapy in children. JOURNAL OF

PAEDIATRICS AND CHILD HEALTH, 52 (2), pp.137-140. https://doi.org/10.1111/jpc.13076.

Persistent Link:

http://hdl.handle.net/11343/290887 